\title{
P-fimbriae-producing septicaemic Escherichia coli from poultry possess fel-related gene clusters whereas pap-hybridizing P-fimbriae- negative strains have partial or divergent $P$ fimbrial gene clusters
}

\author{
Charles M. Dozois, † Josée Harel and John M. Fairbrother \\ Author for correspondence: John M. Fairbrother. Tel: +1 5147735121 ext. 8234. Fax: +1 5147788108 . \\ e-mail: FAIRBRO@ERE.UMONTREAL.CA
}

Département de pathologie et de microbiologie, Faculté de médecine vétérinaire, Université de Montréal, $C P$ 5000, Saint-Hyacinthe, Québec, Canada J2S 7C6

\begin{abstract}
The organization of $P$ fimbrial gene clusters of 13 papC-hybridizing Escherichia coli strains isolated from poultry with colisepticaemia, five P-fimbriaeexpressing (P-positive) and eight P-fimbriae-non-expressing (P-negative), were examined by PCR and by Southern blot hybridization using primers or gene probes specific to the $I, B, A, C$ or $G$ genes. The absence of $P$ fimbrial expression was associated with lack of PCR amplification of one or more of these genes, most commonly the I gene. Restriction endonuclease EcoRI, BamHI or PstI digests of genomic DNA from all strains hybridized with each of the gene probes and demonstrated polymorphisms between P-positive and P-negative strains. Pstl digests of DNA from 12 of the 13 strains, when hybridized with the $A$ gene probe, demonstrated a $0.1 \mathrm{~kb}$ fragment specific to the felA gene which encodes the major structural protein of F11 fimbriae. Hence, only the Ppositive strains contained complete copies of fel-related gene clusters. In contrast, most of the pap-hybridizing P-negative strains contained partial or divergent $P$ fimbrial gene clusters, which explains the lack of $P$ fimbrial expression by these strains.
\end{abstract}

Keywords: Escherichia coli, poultry, P fimbriae, fel gene cluster

\section{INTRODUCTION}

P fimbriae are encoded by pap, prs or related gene clusters (Hacker, 1990). The pap gene cluster from the human urinary tract infection (UTI) Escherichia coli strain J96 has been cloned (Hull et al., 1981) and consists of 11 genes. The $p a p I$ and $p a p B$ genes at the proximal ( $\left.5^{\prime}\right)$ end of the gene cluster encode proteins involved in the environmental regulation and phase variation of expression of $\mathrm{P}$ fimbriae (Nou et al., 1993; Low, 1994). PapA protein subunits comprise the $\mathrm{P}$ fimbrial shaft, PapE protein subunits comprise the tip fibrillum and $p a p G$ encodes the PapG adhesin located at the fibrillar tip (Lindberg et al., 1987; Lund et al., 1988; Kuehn et al., 1992). Three

†Present address: Laboratoire associé INRA-ENVT de Physiopathologie et
Toxicologie Expérimentale, Ecole Nationale Vétérinaire de Toulouse,
Toulouse, France.
Abbreviations: IF, Immunofluorescence; MRHA, mannose-resistant haemagglutination; UTI, urinary tract infection. different classes of G proteins, termed I, II and III, exhibiting different host cell receptor specificities, have been identified on P fimbriae (Strömberg et al., 1990). $\mathrm{PapH}, \mathrm{PapJ}, \mathrm{PapF}$ and PapK are proteins required for the integrity and conformational association of the overall fimbrial adhesin complex (Båga et al., 1988; Tennent $e t$ al., 1990; Jacob-Dubuisson et al., 1993). Biogenesis of the $P$ fimbrial complex requires $\mathrm{PapD}$, which serves to transport structural subunits across the periplasm to the outer membrane, and the PapC protein, which coordinates the ordered assembly of the P fimbrial structure (Jones $e t$ al., 1992). P fimbriae have been grouped into at least 11 serotypes, designated $F 7_{1}$ to $F 16$, based on differences in the major antigenic structural PapA-related proteins (Hacker, 1992).

$P$ fimbriae have been associated with E. coli strains causing UTI in humans (Johnson, 1991) and dogs (Garcia et al., 1988), and causing septicaemia in pigs (Harel et al., 1993). They are also expressed by certain E. coli strains implicated in colisepticaemia and airsacculitis of poultry 
(Dozois et al., 1992; van den Bosch et al., 1993; Pourbakhsh \& Fairbrother, 1994). In a previous study, we determined that $41 \%$ of the isolates from poultry with colisepticaemia and airsacculitis contained papChybridizing DNA (Dozois et al., 1992). However, very few of these isolates expressed $\mathrm{P}$ fimbriae even after growth on different media that enhance the in vitro expression of different fimbrial types (Dozois et al., 1995). When expressed, the P fimbriae were serologically related to F11 fimbriae which are encoded by the fel gene cluster.

The purpose of this study was to analyse and compare the $\mathrm{P}$ fimbrial gene clusters of $\mathrm{P}$-fimbriae-expressing ( $\mathrm{P}$ positive) and $\mathrm{P}$-fimbriae-non-expressing (P-negative) $E$. coli isolated from poultry with colisepticaemia. Strains were examined by PCR amplification of DNA sequences using primers specific for the $I, B, A, C$ and $G$ genes from the $\mathrm{P}$ fimbrial gene cluster and by hybridization of restriction-endonuclease-digested genomic DNA with PCR-derived radiolabelled probes specific for each of these genes. We demonstrated that, although most strains appeared to possess $\mathrm{fel} A$-related sequences, only the $\mathrm{P}$ positive strains possessed a functional copy of a $\mathrm{P}$ fimbrial gene cluster similar to the fel (F11-fimbriae-encoding) gene cluster. In contrast, most of the pap-hybridizing Pnegative strains contained partial or divergent $P$ fimbrial gene clusters.

\section{METHODS}

Bacterial strains. Thirteen E. coli strains from chickens or turkeys with colisepticaemia were examined. These strains were all virulent in 1-d-old chicks, hybridized with a $0.3 \mathrm{~kb}$ probe internal to the $p a p C$ gene, were negative for hybridization with a DNA probe specific for the afa adhesin system and, with the exception of one strain (strain 9), were negative for hybridization with an sfa specific probe (Dozois et al., 1992). These strains were divided into three phenotypic groups, termed I, II and III, based on expression of type 1 and P fimbriae when grown on different media (Dozois et al., 1995). Group I strains $(1,3,9,12$ and 56) expressed P fimbriae after growth on solid media and type 1 fimbriae only after growth in tryptic soy broth (TSB). Group II strains (69, 137, 139 and 151) expressed only type 1 fimbriae after growth on either solid rich, solid minimal or TSB media. Group III strains (14, 33, 165 and 175) expressed only type 1 fimbriae after growth on solid minimal medium or TSB.

E. coli reference strains expressing $\mathrm{P}$ fimbriae of different serological types were C1976 (O1:K1:H7:F11), C1212 $\left(\mathrm{O} 6: \mathrm{K} 2: \mathrm{H} 1: \mathrm{F}_{1}, \quad \mathrm{~F} 72\right), \quad \mathrm{C} 1254 \quad\left(\mathrm{O} 75: \mathrm{K}^{-}: \mathrm{H} 5: \mathrm{F} 8\right), \quad \mathrm{C} 1979$ (O16:K1:H五12) (Ørskov \& Orskov, 1983), J96 (O4:K6:H5:F13) (Hull et al., 1985) and 3669 (O2:K5:H1:F9) (Korhonen et al., 1982). E. coli strain HB101 harbouring recombinant plasmid pPAP5, containing the pap gene cluster encoding F13 fimbriae from strain J96, was kindly provided by B.-I. Marklund (University of Umeå, Sweden) and strain HB101 harbouring recombinant plasmid pPIL-291-15, containing the fel gene cluster encoding F11 fimbriae from strain C1976, was kindly provided by J. F. van den Bosch (Intervet International, Boxmeer, The Netherlands) (de Ree et al., 1985). E. coli K-12 strain AAEC189 (kindly provided by Dr I. C. Blomfield, Wake Forest University, NC, USA) was used as a negative control for Southern blot hybridizations.
Preparation of total genomic and plasmid DNA extracts. Plasmid DNA from the HB101 strains was extracted and purified by ultracentrifugation in a caesium chloride gradient (Maniatis et al., 1982). Genomic DNA from the colisepticaemic and reference or control strains was prepared from overnight cultures in $5 \mathrm{ml}$ Luria-Bertani broth and was extracted as described by Marmur (1961).

PCR amplification. Five sets of primers for amplification of sequences specific for the $I, B, A, C$ and $G$ genes of the $\mathrm{P}$ fimbrial gene cluster were used to screen strains for the presence of pap-related genes (Table 1). These primers were chosen to examine for the presence of $\mathrm{P}$ fimbrial DNA sequences encompassing the entire pap operon. The $G$ primer set is specific for genes encoding the class II and class III but not the class I G adhesins (Marklund et al., 1992). The $A$ primer set was designed to amplify any of the known $A$ genes of $\mathrm{P}$ fimbrial gene clusters.

PCR was performed as described by Daigle et al. (1994). PCR amplifications consisted of 25 cycles of denaturation at $94{ }^{\circ} \mathrm{C}$ for $2 \mathrm{~min}$, annealing for $1 \mathrm{~min}$ at the temperatures indicated in Table 1 , and extension at $72{ }^{\circ} \mathrm{C}$ for $1 \mathrm{~min}$ in a thermal cycler (MJ Research, Watertown, MA, USA). Ten microlitres of each of the reaction mixtures was then analysed by electrophoresis on a $1.5 \%(\mathrm{w} / \mathrm{v})$ agarose gel and the reaction products were visualized by staining with ethidium bromide. A reagent blank, which contained all components of the reaction mixture except the template DNA, was included in every amplification reaction.

Alkaline blot DNA transfers and hybridization with DNA probes. Bacterial genomic DNA was digested with restriction endonucleases EcoRI, BamHI, or PstI and the digests were separated by electrophoresis in $0.5 \%$ or $1 \%$ agarose horizontal slab gels. DNA fragments were transferred from the gels to Zeta-Probe GT blotting membranes by alkaline blotting as recommended by the manufacturer (Bio-Rad) (Reed \& Mann, 1985). Filters were prehybridized for $5 \mathrm{~min}$ at $65^{\circ} \mathrm{C}$ in hybridization solution, $0.25 \mathrm{M} \mathrm{Na}_{2} \mathrm{HPO}_{4}, \mathrm{pH} 7 \cdot 2$ containing $7 \%(\mathrm{w} / \mathrm{v})$ SDS. Hybridization with heat-denatured labelled probe was carried out in fresh hybridization solution overnight at $65{ }^{\circ} \mathrm{C}$ with agitation. Membranes were washed twice for $45 \mathrm{~min}$ in $20 \mathrm{mM} \mathrm{Na}_{2} \mathrm{HPO}_{4}, \mathrm{pH} 7.2$ containing $5 \%$ SDS, followed by two washes for $45 \mathrm{~min}$ in $20 \mathrm{mM} \mathrm{Na}_{2} \mathrm{HPO}_{4}, \mathrm{pH} 7 \cdot 2$ containing $1 \%$ SDS. The filters were then exposed to Kodak $\mathrm{X}$-Omat AR film (Eastman Kodak) at $-70^{\circ} \mathrm{C}$.

For generation of DNA probes, PCR-derived DNA fragments from appropriate strains or plasmids were eluted from lowmelting-temperature agarose (Maniatis et al., 1982), and radiolabelled with $\left[\alpha^{-32} \mathrm{P}\right] \mathrm{dCT}$ P using a random priming kit for labelling oligonucleotides (Pharmacia LKB Biotechnology). Probes specific for $I, B$ or $C$ genes from $P$ fimbrial gene clusters were PCR products derived from plasmid PPAP5 by using the $I, B$ and $C$ primer sets, respectively (Table 1). The probe specific for the $A$ gene from P fimbrial gene clusters was the PCR product derived from the fel $A$ gene of F11 reference strain C1976 by using the $A$ primer set (Table 1). The DNA probe specific for all three classes of $G$ genes from $\mathrm{P}$ fimbrial gene clusters was derived from strain $\mathrm{C} 1212$ by using the $G$ primer set. Endonuclease-digested genomic DNA from either strain J96 or C1976 or from plasmid pPIL-219-15 was used as a positive control. Endonuclease-digested genomic DNA from strain AAEC189 was used as a negative control.

Plasmids used for complementation. Plasmid pFELIA contains a PCR amplicon insert of the felI, felB and fel $A$ genes from plasmid pPIL-219-15 that was cloned into plasmid pCRII (Invitrogen). The cloned PCR product was amplified as described above using the $I$ forward primer (Table 1) and a 
Table 1. Base sequences of primer sets, annealing temperatures and predicted sizes of the PCR-amplified products from $P$ fimbrial DNA sequences

\begin{tabular}{|c|c|c|c|c|c|c|c|}
\hline $\begin{array}{l}\text { Primer } \\
\text { set }\end{array}$ & $\begin{array}{l}\text { P fimbrial } \\
\text { gene } \\
\text { specificity }\end{array}$ & & $\begin{array}{l}\text { Primer oligonucleotide sequence } \\
\qquad\left(5^{\prime}-3^{\prime}\right)^{*}\end{array}$ & $\begin{array}{l}\text { Sequences derived } \\
\text { from }\end{array}$ & $\begin{array}{l}\text { Predicted } \\
\text { size (bp) }\end{array}$ & $\begin{array}{l}\text { Annealing } \\
\text { temperature }\end{array}$ & Reference \\
\hline$I$ & $I$ & $\begin{array}{l}(\mathrm{F}) \\
(\mathrm{R})\end{array}$ & $\begin{array}{l}\text { GAGTTATTAAGTTGTGAAGAA } \\
\text { ATGAGTGAATATATGAAGAATG }\end{array}$ & Marklund et al. (1992) & 239 & $45^{\circ} \mathrm{C}$ & This work \\
\hline$B$ & $B$ & $\begin{array}{l}(\mathrm{F}) \\
(\mathrm{R})\end{array}$ & $\begin{array}{l}\text { CCGACAGAAGGGGGAAACA } \\
\text { GATAGTCCTTCATAGCCAGA }\end{array}$ & Marklund et al. (1992) & 180 & $50^{\circ} \mathrm{C}$ & This work \\
\hline$A$ & $A$ & $\begin{array}{l}(\mathrm{F}) \\
(\mathrm{R})\end{array}$ & 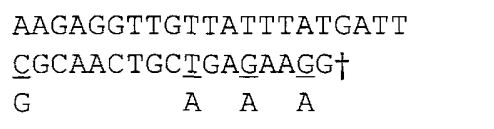 & $\begin{array}{l}\text { Denich et al. (1991) } \\
\text { Marklund et al. (1992), } \\
\text { van Die et al. (1986) }\end{array}$ & 550 & $45^{\circ} \mathrm{C}$ & This work \\
\hline C & C & $\begin{array}{l}(\mathrm{E}) \\
(\mathrm{R})\end{array}$ & $\begin{array}{l}\text { GACGGCTGTACTGCAGGGTGTGGCG } \\
\text { ATATCCTTTCTGCAGGATGCAATA }\end{array}$ & Norgren et al. (1987) & 328 & $60^{\circ} \mathrm{C}$ & $\begin{array}{l}\text { Le Bouguenec } \\
\text { et al. (1992) }\end{array}$ \\
\hline$G \ddagger$ & $G$ & $\begin{array}{l}(\mathrm{F}) \\
(\mathrm{R})\end{array}$ & $\begin{array}{l}\text { CTGTAATTACGGAAGTGATTTCTG } \\
\text { CTCTATCCGGCTCCGGATAACCAT }\end{array}$ & Marklund et al. (1992) & 1055 & $55^{\circ} \mathrm{C}$ & $\begin{array}{l}\text { Marklund } e t \\
\text { al. (1992) }\end{array}$ \\
\hline
\end{tabular}

* $\mathrm{F}$ indicates a forward direction primer and $\mathrm{R}$ indicates a reverse direction primer.

†Degenerate oligonucleotide: underlined positions contain either the upper or lower base.

$\ddagger$ Primers for the $G$ gene are specific for genes encoding class II and class III but not class I G adhesins.

reverse primer complementary to the $3^{\prime}$ end of the $f e l A$ gene, $5^{\prime}$ TTACTGGTAAC'TTAAATTAAAGGT-3', with an annealing temperature of $45^{\circ} \mathrm{C}$.

Plasmid pPIB contains a PCR amplicon insert of the papI and $p a p B$ genes from plasmid pPAP5 that was cloned into plasmid pCRII. The cloned PCR product was amplified as described above using the $I$ forward primer (Table 1 ) and a reverse primer complementary to the $3^{\prime}$ end of the $p a p B$ gene, $5^{\prime}$-AGGGCTTCT'T'TT'T'TATCTTC-3'.

Complementation of strains grown on tryptic soy agar or Luria-Bertani agar with appropriate antibiotics was tested by immunofluorescence (IF) using absorbed polyclonal anti-F11 serum for mannose-resistant haemagglutination (MRHA), and by Gala1-4Gal- and GalNAc-GalNAc-coated latex bead agglutination as previously described (Dozois et al., 1992, 1994).

\section{RESULTS}

\section{Detection of DNA sequences specific to pap-related gene clusters}

The 13 E. coli strains from cases of avian colisepticaemia demonstrated five distinct patterns based on the results of amplification by PCR using the various sets of primers specific for genes at different locations on the pap operon. The relationship of these patterns to the three phenotypic groups that we described previously (Dozois et al., 1995) is shown in Table 2. The avian septicaemic strains and Pfimbriated reference strains were all positive for amplification of sequences specific to the $C$ and $B$ genes. The Pfimbriated reference strains and the five P-positive avian E. coli strains (phenotype group I) were also positive for amplification of the $I, A$ and $G$ genes. In contrast, none of the P-negative avian E. coli strains, with the exception of strain 69 , were positive for amplification of the $I$ gene.
In addition, four of the eight P-negative avian strains, all belonging to serogroup $\mathrm{O} 78$ (phenotype group III) were negative for amplification of the $A$ gene. Six of the eight P-negative strains were positive for amplification of $G$ genes using primers specific for class II and class III adhesins (Marklund et al., 1992). The negative control was not amplified by any of the gene primer sets. In all reactions, using sets of primers specific for the different genes, amplification products were of the expected sizes indicated in Table 1.

In contrast to the PCR results, EcoRI digests of genomic DNA from each of the avian E. coli strains were positive for hybridization in Southern blots with each of the five probes specific for the $I, B, A, C$ and $G$ genes within the P fimbrial gene cluster (Table 3 ). The avian E. coli strains exhibited six distinct hybridization patterns. The five Ppositive strains (phenotype group I) contained a single EcoRI fragment of $17 \mathrm{~kb}$ that hybridized with each of the five gene probes, as was observed for reference strain C1976, which produces F11 fimbriae. Three of the P-negative strains (phenotype group II) each contained a single EcoRI fragment of either $15 \mathrm{~kb}$ or $18 \mathrm{~kb}$ that hybridized with each of the five gene probes. Interestingly, the five serogroup O78 P-negative strains demonstrated two hybridizing fragments (three in the case of strain 139), one EcoRI fragment of $7 \mathrm{~kb}$ that hybridized with the $I, B$ and $A$ gene probes and a second, larger EcoRI fragment of $18 \mathrm{~kb}$ that hybridized with the $A, C$ and $G$ gene probes. EcoRI-digested DNA from strain 139 also exhibited a $13 \mathrm{~kb}$ fragment that hybridized with all five probes. Southern blots of $\mathrm{BamHI}$ digests of genomic DNA from the avian E. coli gave hybridization patterns similar to those obtained with EcoRI digests 
Table 2. PCR profiles of pathogenic $E$. coli strains from poultry and reference strains expressing $P$ fimbriae using primer sets specific for genes in pap- and related gene clusters

\begin{tabular}{|c|c|c|c|c|c|c|}
\hline \multirow[t]{2}{*}{ Strains* } & \multicolumn{5}{|c|}{$\begin{array}{l}\text { PCR amplification products } \\
\text { specific for the indicated genes } \\
\text { of the pap-gene cluster using } \\
\text { the primer sets }\end{array}$} & \multirow[t]{2}{*}{$\begin{array}{c}\text { P fimbrial } \\
\text { expression } t\end{array}$} \\
\hline & $I$ & $B$ & $A$ & $C$ & $G$ & \\
\hline $\begin{array}{l}\text { P-fimbriated reference strains } \\
\text { C1212 (F7 }, \text { F7 } 2 \text { ), C1254 (F8), } 3669 \text { (F9), } \\
\text { C1979 (F12), C1976 (F11), J96 (F13) }\end{array}$ & + & + & + & + & + & + \\
\hline $\begin{array}{l}\text { Strains from avian septicaemia } \ddagger \\
\text { Group I } \\
\quad 1,3,12,56(\mathrm{O} 1), 9(\mathrm{O} 18)\end{array}$ & + & + & + & + & + & + \\
\hline $\begin{array}{l}\text { Group II } \\
\qquad 69(\mathrm{O} 22) \\
137(\mathrm{O} 1), 151(\mathrm{O} 2) \\
139(\mathrm{O} 78)\end{array}$ & $\begin{array}{l}+ \\
- \\
-\end{array}$ & $\begin{array}{l}+ \\
+ \\
+\end{array}$ & $\begin{array}{l}+ \\
+ \\
+\end{array}$ & $\begin{array}{l}+ \\
+ \\
+\end{array}$ & $\begin{array}{l}+ \\
- \\
+\end{array}$ & $\begin{array}{l}- \\
- \\
-\end{array}$ \\
\hline $\begin{array}{l}\text { Group III } \\
\qquad 14,33,165,175 \text { (O78) }\end{array}$ & - & + & - & + & + & - \\
\hline
\end{tabular}

* P fimbrial serotypes are indicated in parentheses.

† Expression of P fimbriae determined by MRHA and immunotechniques (Dozois et al., 1995).

$\ddagger$ Phenotypic groups I, II and III as described previously (Dozois et al., 1995).

Table 3. Sizes of restriction endonuclease EcoRI fragments containing DNA sequences related to $\mathbf{P}$ fimbrial gene clusters by Southern hybridization

\begin{tabular}{|c|c|c|c|c|}
\hline \multirow[t]{2}{*}{ Strains* } & \multicolumn{4}{|c|}{$\begin{array}{c}\text { Size }(\mathrm{kb}) \text { of fragments detected by } \\
\text { gene probe: }\end{array}$} \\
\hline & $I$ or $B \dagger$ & $A$ & $C$ & $G$ \\
\hline \multicolumn{5}{|c|}{ P-fimbriated reference strains } \\
\hline J96 (F13) & 13,19 & 13,19 & 13,19 & 13,19 \\
\hline C1976 (F11) & 17 & 17 & 17 & 17 \\
\hline \multicolumn{5}{|c|}{ Strains from avian septicaemia $\Varangle$} \\
\hline 1, 3, 12, $56(\mathrm{O} 1), 9$ (O18) & 17 & 17 & 17 & 17 \\
\hline \multicolumn{5}{|l|}{ Group II } \\
\hline $69(\mathrm{O} 22)$ & 18 & 18 & 18 & 18 \\
\hline $137(\mathrm{O} 1), 151(\mathrm{O} 2)$ & 15 & 15 & 15 & 15 \\
\hline $139(\mathrm{O} 78)$ & 13,7 & $18,13,7$ & 18,13 & 18,13 \\
\hline \multicolumn{5}{|l|}{ Group III } \\
\hline $14,165,175(\mathrm{O} 78)$ & 7 & 18,7 & 18 & 18 \\
\hline $33(\mathrm{O} 78)$ & 7 & 19,7 & 19 & 19 \\
\hline
\end{tabular}

*P fimbrial serotypes are indicated in parentheses.

$\dagger$ Hybridization patterns using the $I$ or $B$ probes were identical.

$\ddagger$ Phenotypic groups I, II and III as described previously (Dozois et al., 1995).

using the five gene probes, with 078 strains also demonstrating fragments that only hybridized with the $I$, $B$ and $A$ gene probes, and fragments that only hybridized with the $A, C$ and $G$ gene probes (data not shown). Negative controls did not hybridize with any of the gene probes. 
Table 4. Sizes of restriction endonuclease Pstl fragments containing DNA sequences related to $P$ fimbrial gene clusters by Southern hybridization

\begin{tabular}{|c|c|c|}
\hline \multirow[t]{2}{*}{ Strains* } & \multicolumn{2}{|c|}{$\begin{array}{l}\text { Size }(\mathrm{kb}) \text { of fragments } \\
\text { detected by gene probe: }\end{array}$} \\
\hline & $I$ or $B \dagger$ & $A$ \\
\hline \multicolumn{3}{|c|}{ P-fimbriated reference strains } \\
\hline $\mathrm{J} 96(\mathrm{~F} 13)$ & 5,6 & 5,6 \\
\hline C1976 (F11) & 2 & $2,0 \cdot 1$ \\
\hline \multicolumn{3}{|l|}{$\begin{array}{l}\text { Strains from avian } \\
\text { septicaemia } \ddagger\end{array}$} \\
\hline $1,3,12,56(\mathrm{O} 1), 9(\mathrm{O} 18)$ & 2 & $2,0 \cdot 1$ \\
\hline \multicolumn{3}{|l|}{ Group II } \\
\hline $69(\mathrm{O} 22)$ & 12 & 12 \\
\hline $137(\mathrm{O} 1), 151(\mathrm{O} 2)$ & $2 \cdot 1$ & $2 \cdot 1,0 \cdot 1$ \\
\hline $139(\mathrm{O} 78)$ & $12,2 \cdot 1$ & $12,7,2 \cdot 1,0 \cdot 1$ \\
\hline \multicolumn{3}{|l|}{ Group III } \\
\hline $14,33,165,175(\mathrm{O} 78)$ & 12 & $12,7,0 \cdot 1$ \\
\hline
\end{tabular}

* P fimbrial serotypes are indicated in parentheses.

† Hybridization patterns using the $I$ or $B$ probes were identical. $\ddagger$ Phenotypic groups I, II and III as described previously (Dozois $e t$ al., 1995).
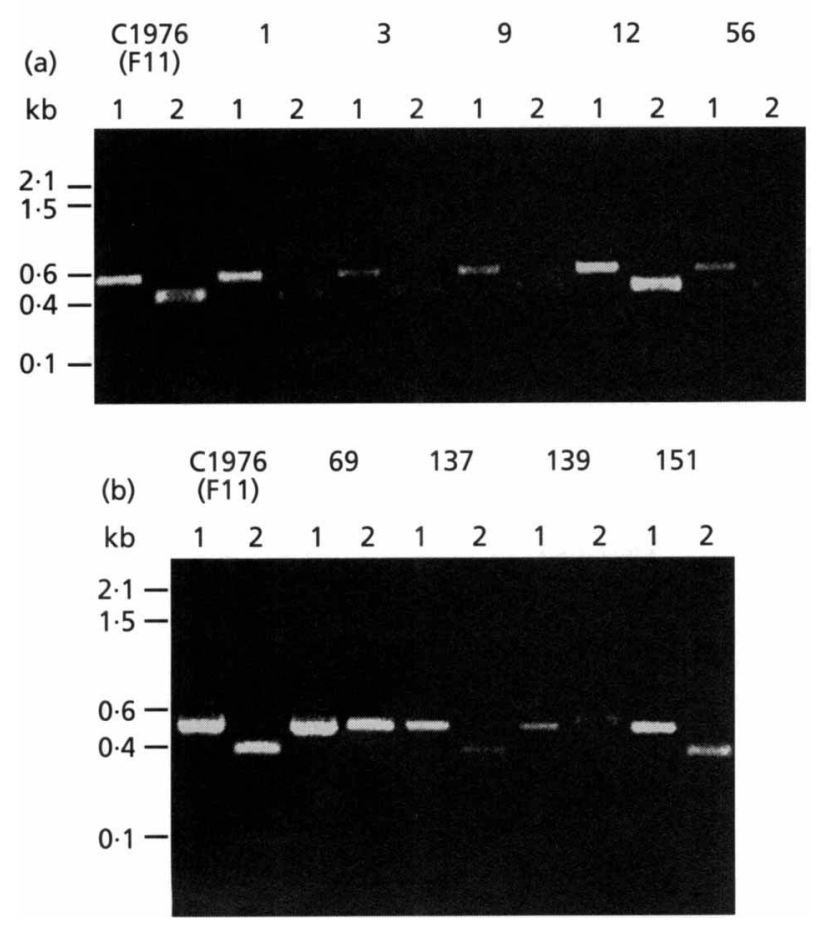

Fig. 1. $\mathrm{PCR}$ products derived from the $A$ genes of avian $E$. coli strains with P-positive (group I) (a) and P-negative (group II) (b) phenotypes. Samples were amplified using the $A$ primer set. Lanes: 1, undigested samples; 2, samples digested with Pstl. Samples were electrophoresed on $2 \%$ agarose gels and strains are labelled at the top of the figures.

\section{Pstl digests demonstrate $I$ and $B$ gene polymorphisms in the $5^{\prime}$ region of pap-related gene clusters of avian septicaemic $E$. coli}

P fimbrial gene clusters contain a variable PstI site downstream of the $I$ gene and a conserved $P_{s t} \mathrm{I}$ site within the $H$ gene (Arthur et al., 1989; Marklund et al., 1992; Maiti et al., 1993). In addition, DNA sequence data indicate that certain P fimbrial clusters, namely, $f e l$ (F11), $f_{s o}\left(\mathrm{~F} 7_{1}\right)$, and $f n i(\mathrm{~F} 9)$ contain $P_{s t} \mathrm{I}$ sites within the $A$ gene (van Die et al., 1986; Denich et al., 1991).

PstI digests examined by Southern blot hybridization with the $I$ or $B$ gene probe revealed polymorphisms among the $\mathrm{P}$ fimbrial sequences of the septicaemic E. coli from poultry (Table 4). In the case of the five P-positive strains these gene probes hybridized with a $2 \mathrm{~kb}$ fragment, as was also observed for the F11-encoding $f e l$ gene cluster of strain C1976. With PstI-digested DNA from the Pnegative strains $137(\mathrm{O} 1)$ and 151 (O2) both probes hybridized with a $2 \cdot 1 \mathrm{~kb}$ fragment. With PstI digests of DNA from the serogroup O78 strains (phenotype group III) and strain 69 (O22) both probes showed hybridization with a $12 \mathrm{~kb}$ fragment. With PstI digests of DNA from serogroup $O 78$ strain 139 the $I$ or $B$ gene probe also hybridized with a $2 \cdot 1 \mathrm{~kb}$ fragment in addition to the $12 \mathrm{~kb}$ fragment.

\section{Avian E. coli strains contain P fimbrial DNA sequences that share conserved Pstl restriction sites with felA}

Southern blot hybridization of PstI digests with the $A$ gene probe revealed that the five P-positive strains and two of the P-negative strains, 137 and 151, yielded the same band patterns as observed with the $I$ and $B$ probes, although an additional band of about $0 \cdot 1 \mathrm{~kb}$ was observed (Table 4). This hybridization pattern was also observed for the PstI-digested DNA from strain C1976 bearing the fel gene cluster. The five P-negative O78 strains also demonstrated the same hybridizing $12 \mathrm{~kb}$ fragment as seen in Southern analysis using the $I$ and $B$ probes, as well as common $7 \mathrm{~kb}$ and $0 \cdot 1 \mathrm{~kb}$ fragments. In addition, for strain 139, Southern blots of PstI digests with the $A$ gene probe revealed a hybridizing $2.1 \mathrm{~kb}$ fragment. Strain 69 only demonstrated the same $12 \mathrm{~kb}$ fragment as hybridized with the $I$ and $B$ probes. Pst I digests of DNA from strain J96, the reference F13 strain, demonstrated two distinct bands of $6 \mathrm{~kb}$ and $5 \mathrm{~kb}$ when hybridized with the $I, B$ and $A$ probes (Table 4).

The fel $A$ gene contains internal Pst I sites, which produce a $108 \mathrm{bp}$ fragment internal to $\mathrm{fel} A$. To more precisely determine whether there were any $P_{s} t \mathrm{I}$ sites within the $A$ genes of some of the avian E. coli strains, we digested the PCR-amplified $A$ gene products from the nine avian $E$. coli strains with PstI (Table 2, Fig. 1a, b). For the five strains expressing $\mathrm{P}$ fimbriae, as well as for P-negative strains 151 and 137, the same two restriction fragments as for strain C1976 containing felA, i.e. of $430 \mathrm{bp}$ and $108 \mathrm{bp}$, were observed. Interestingly, the results for strain 139 demonstrated that this strain contains at least two 
copies of pap-related $A$ genes, one which demonstrated a pattern identical to that of fel $A$ and another which contained no PstI sites. No PstI digestion products were observed for strain 69.

These results, and the observation of $0 \cdot 1 \mathrm{~kb}$ hybridizing bands in the alkaline blots of Pst I digests of genomic DNA from eight of these nine avian $E$. coli strains (except strain 69) that hybridized with the $A$ gene probe (Table 4 ), are in accordance with the presence of $P_{s t} \mathrm{I}$ sites similar to those observed in the $\mathrm{fel} A$ gene of reference strain C1976. These results suggest that these eight avian $E$. coli strains contain sequences related to $f e l A$, which encodes the major structural subunit of F11 fimbriae.

\section{Complementation with I, B and $A$ genes from $P$ fimbrial gene clusters}

To investigate whether the $P$ fimbrial gene clusters in P-negative avian $E$. coli might be functional for the biogenesis of $\mathrm{P}$ fimbriae, five of these strains $(69,33,165$, 151 and 139) were transformed with plasmids pFELIA and $\mathrm{pPIB}$ separately, which bear functional felI, felB and $f e l A$, or $p a p I$ and $p a p B$ genes, respectively. Fimbrial expression in transformed strains was tested by IF using absorbed polyclonal anti-F11 serum and by haemagglutination. All of these strains were previously shown to be negative for production of MRHA with human, rabbit, ovine and porcine erythrocytes (Dozois et al., 1992, 1994).

Both plasmids pFELIA and pPIB complemented strain 69 for expression of $\mathrm{P}$ fimbriae. Interestingly, when complemented, strain 69 was MRHA-positive for ovine and human $\mathrm{A}$, but not human $\mathrm{O}$ erythrocytes and also agglutinated GalNAc-GalNAc-coated latex beads. These results suggest strain 69 contains a P fimbrial gene cluster bearing a $G$ gene encoding an adhesin with class III specificity. When strain 69 was complemented with plasmid pFELIA, it demonstrated a positive reaction in IF tests using anti-F11 antiserum, whereas upon complementation with plasmid pPIB the IF test with anti-F11 serum was negative. This result further suggests that strain 69 contains an $A$ gene encoding a major subunit that is divergent from the fel $A$ F11-subunit-encoding gene. Complementation with either plasmid pFELIA or plasmid PPIB did not allow $\mathrm{P}$ fimbrial expression in any of the other strains, as they were always negative in IF tests with anti-F11 serum or MRHA.

\section{DISCUSSION}

We have previously defined three phenotypic groups among avian $E$. coli strains based on expression of $P$ fimbriae and type 1 fimbriae by bacteria grown under different conditions (Dozois et al., 1995). These groups corresponded well with the different PCR and Southern hybridization band profiles observed in our present study. The five P-positive strains that exhibited PCR amplification and DNA hybridization patterns similar to those of the F11 reference strain comprised phenotypic group I, whereas P-negative strains from phenotypic groups II and III exhibited distinct patterns on Southern blots and were generally negative for PCR amplification of the $I$ gene. Strains belonging to each of the different phenotypic groups were often of a particular serogroup and exhibited similar organization of $\mathrm{P}$ fimbrial genes.

The restriction enzymes BamHI and EcoRI, which do not generally cut within the pap operon or related gene clusters, and Pst $\mathrm{I}$, which cuts at several sites internal to $\mathrm{P}$ fimbrial gene clusters (Arthur et al., 1989; Plos et al., 1990; Maiti et al., 1993), were used to analyse P fimbrial gene copy number and organization. In the present study, genetic analyses of $P$ fimbrial gene clusters from avian $E$. coli demonstrated that strains which express $\mathrm{P}$ fimbriae contain one complete copy of a P fimbrial gene cluster bearing a $5^{\prime}$ end similar to that of the fel cluster encoding F11 fimbriae (de Ree et al., 1985; van Die et al., 1986). In contrast, Southern hybridization and complementation studies suggest that $p a p$-hybridizing strains which do not express $\mathrm{P}$ fimbriae contain partial or modified copies of $\mathrm{P}$ fimbrial gene clusters. Hybridization experiments using gene probes covering the $5^{\prime}$ or $3^{\prime}$ ends of the operon suggest that each of the serogroup O78 strains in this study contains two non-contiguous partial copies of $\mathrm{P}$ fimbrial sequences that may have been interrupted within the $A$ gene. However, we cannot rule out the possibility that these strains may bear one or more $A$ genes that are divergent from the known $A$ genes encoding the different major P-fimbrial subunits. Although certain P-negative strains demonstrated hybridization profiles similar to $\mathrm{P}$ positive strains, lack of complementation with plasmids bearing genes from the $5^{\prime}$ end $(I, B, A)$ of $\mathrm{P}$ fimbrial gene clusters in most of these strains suggests that they bear non-functional copies of $\mathrm{P}$ fimbrial gene clusters.

When complemented with plasmids bearing functional $p a p I$ and $p a p B$ or $f e l I, f e l B$ and $f e l A$ genes, strain 69 produced $P$ fimbriae that exhibited class III type Gadhesin specificity as determined by a GalNAc-GalNAccoated latex bead agglutination test and MRHA of sheep and human A erythrocytes. To our knowledge, this is the first time this type of adhesin specificity has been described for an E. coli strain from poultry. We have observed avian E. coli strains bearing P fimbriae expressing class II type specificity (Dozois et al., 1992, 1995). In addition, class Irelated $G$ adhesins, which had previously only been described for $\mathrm{P}$ fimbriae encoded by the pap gene cluster (Strömberg et al., 1990; Marklund et al., 1992), have been identified on three avian E. coli strains (Garcia-Gonzalez, 1992).

Differences were observed between the PCR-amplified gene products and the hybridization reactions for the presence of $p a p$-related genes in Southern blots. Minor differences in the DNA sequences between specific primer oligonucleotides and target genes can result in lack of PCR amplification and may explain the absence of PCR amplification of some of the genes in certain strains. However, the PCR primer sequences used appear to be conserved, as the pap-related operons from the six reference strains expressing different $\mathrm{P}$ fimbrial serotypes 
were positive for PCR amplification with each of the primer sets tested. All of the P-negative strains, except strain 69, were negative for PCR amplification of the $I$ gene. papI and homologous genes have been shown to be strong transcriptional regulators for the expression of $\mathrm{P}$ fimbrial genes (Forsman et al., 1992; Nou et al., 1993) and are directly involved with leucine-responsive regulatory protein (Lrp) in the dam methylation-dependent regulation of phase variation and expression of $\mathrm{P}$ fimbriae (Nou et al., 1993). Differences in the DNA sequences of the $I$ genes or lack of expression of the $I$ gene product could modify or inhibit expression of $\mathrm{P}$ fimbriae in these strains. The $A$ gene primers used were designed to permit PCR amplification of any of the known $A$ genes, which contain variable $5^{\prime}$ and $3^{\prime}$ ends and encode major subunits from different $\mathrm{P}$ fimbrial serotypes. Lack of PCR amplification of the $A$ gene, only observed in four of the serogroup O78 strains, further suggests that these strains may contain non-contiguous partial copies of $\mathrm{P}$ fimbrial sequences that may have been interrupted within the $A$ gene.

Most of the avian E. coli strains exhibited a similar Pst $\mathrm{I}$ cleavage site polymorphism to that of the fel $A$ gene with respect to digestion of PCR-amplified gene products and Southern blot hybridization of genomic DNA. Our results strongly suggest that 12 of the 13 avian strains contain sequences related to fel $A$, the gene encoding the F11 major structural protein, corroborating previous observations that F11 is the predominant serotype of $P$ fimbriae expressed by E. coli from poultry (van den Bosch et al., 1993; Pourbakhsh \& Fairbrother, 1994; Dozois et al., 1995). This is an unexpected finding considering that the strains implicated in avian colisepticaemia belong to a number of different serogroups, and that numerous $\mathrm{P}$ fimbrial serotypes have been found in E. coli associated with UTI in humans (Hacker, 1990, 1992; Johnson, 1991). However, in addition to avian pathogenic E. coli, some $E$. coli strains associated with septicaemia in pigs and calves (Harel et al., 1993) express F165 fimbriae that are closely related to serotype F11 (Maiti et al., 1994), suggesting F11 fimbriae are frequently expressed by pathogenic E. coli isolated from animals with septicaemia.

\section{ACKNOWLEDGEMENTS}

This work was supported by the Ministère de l'Enseignement Supérieure de la Science (Québec), the Conseil de Recherches en Pêche et en Agro-Alimentaire du Québec grant 2242, the Fonds pour la Formation des Chercheurs et l'Aide à la Recherche du Québec (FCAR), and Natural Sciences and Engineering Research Council grant 2294. C. M. D. was funded by a doctorate level scholarship from the FCAR.

\section{REFERENCES}

Arthur, M., Campanelli, C., Arbeit, R. D., Kim, C., Steinbach, S., Johnson, C. E., Rubin, R. H. \& Goldstein, R. (1989). Structure and copy number of gene clusters related to the pap $\mathbf{P}$-adhesin operon of uropathogenic Escherichia coli. Infect Immun 57, 314-321.

Båga, M., Norgren, M. \& Normark, S. (1988). Biogenesis of E. coli Pap pili: $\mathrm{PapH}$, a minor pilin subunit involved in cell anchoring and length modulation. Cell 49, 241-251. van den Bosch, J. F., Hendriks, J. H. I. M., Gladigau, I., Willems, H. M. C., Storm, P. K. \& de Graaf, F. K. (1993). Identification of F11 fimbriae on chicken Eschericbia coli strains. Infect Immun 61, 800-806.

Daigle, F., Harel, J., Fairbrother, J. M. \& Lebel, P. (1994). Expression and detection of pap-, sfa-, and afa-encoded fimbrial adhesin systems among uropathogenic Escherichia coli. Can J Microbiol 40, 286-291.

Denich, K. L., Blyn, B., Craiu, A., Braaten, B. A., Hardy, J., Low, D. A. \& O'Hanley, P. (1991). DNA sequences of three $p a p A$ genes from uropathogenic Eschericbia coli strains: evidence of structural and serological conservation. Infect Immun 59, 3849-3858.

van Die, I., Dijksterhuis, M., de Cock, H., Hoekstra, W. \& Bergmans, H. (1986). Structural variation of P-fimbriae from uropathogenic Escherichia coli. In Protein-Carbohydrate Interactions in Biological Systems, pp. 39-46. Edited by D. A. Lark. London: Academic Press.

Dozois, C. M., Fairbrother, J. M., Harel, J. \& Bossé, M. (1992). papand $p i l$-related DNA sequences and other virulence determinants associated with Escherichia coli isolated from septicemic chickens and turkeys. Infect Immun 60, 2648-2656.

Dozois, C. M., Chanteloup, N., Dho-Moulin, M., Brée, A., Desautels, C. \& Fairbrother, J. M. (1994). Bacterial colonization and in vivo expression of F1 (type 1) fimbrial antigens in chickens experimentally infected with pathogenic Eschericbia coli. Avian Dis 38, 231-238.

Dozois, C. M., Pourbakhsh, S. A. \& Fairbrother, J. M. (1995). Expression of $\mathrm{P}$ and type 1 (F1) fimbriae in pathogenic Escherichia coli from poultry. Vet Microbiol 45, 297-309.

Forsman, K., Sondén, B., Göransson, M. \& Uhlin, B. E. (1992). Antirepression function in Escbericbia coli for the cAMP-CRP receptor protein transcriptional activator. Proc Natl Acad Sci US A 89, 9880-9884.

Garcia, E., Bergmans, H. E. N., van den Bosch, J. F., Ørskov, I., van der Zeist, B. A. M. \& Gaastra, W. (1988). Isolation and characterisation of dog uropathogenic Escherichia coli strains and their fimbriae. Antonie Leeuwenhoek 54, 149-163.

Garcia-Gonzalez, E. (1992). Adhesion factors of extraintestinal Escherichia coli strains. $\mathrm{PhD}$ thesis, University of Utrecht.

Hacker, J. (1990). Genetic determinants coding for fimbriae and adhesins of extraintestinal Eschericbia coli. Curr Top Microbiol Immunol 151, 1-27.

Hacker, J. (1992). Role of fimbrial adhesins in the pathogenesis of Escherichia coli infections. Can J Microbiol 38, 720-727.

Harel, J., Fairbrother, J., Forget, C., Desautels, C. \& Moore, J. (1993). Virulence factors associated with F165-positive Escherichia coli isolated from piglets and calves. Vet Microbiol 38, 139-155.

Hull, R. A., Gill, R. E., Hsu, P., Minshew, B. H. \& Falkow, S. (1981). Construction and expression of recombinant plasmids encoding type 1 or D-mannose-resistant pili from a urinary tract infection Escherichia coli isolate. Infect Immun 33, 933-938.

Hull, S., Clegg, S., Svanborg Eden, C. \& Hull, R. (1985). Multiple forms of genes in pyelonephritogenic Escherichia coli encoding adhesins binding globoseries D-glycolipid receptors. Infect Immun 47, $80-83$.

Jacob-Dubuisson, F., Heuser, J., Dodson, K., Normark, S. \& Hultgren, S. (1993). Initiation of assembly and association of the structural elements of a bacterial pilus depend on two specialized tip proteins. EMBO J 12, 837-847.

Johnson, J. R. (1991). Virulence factors in Escherichia coli urinary tract infections. Clin Microbiol Rev 4, 80-128.

Jones, C. H., Jacob-Dubuisson, F., Dodson, K., Kuehn, M. J., Slonim, L., Striker, R. \& Hultgren, S. J. (1992). Adhesin presentation 
in bacteria requires molecular chaperones and ushers. Infect Immun 60, 4445-4451.

Korhonen, T. K., Văisănen, V., Kallio, P., Nurmiaho-Lassila, E.-L., Ranta, H., Siltonen, A., Elo, J., Svenson, S. B. \& Svanborg-Edén, C. (1982). The role of pili in the adhesion of Escherichia coli to human urinary tract epithelial cells. Scand J Infect Dis Suppl 33, 26-31.

Kuehn, M. J., Heuser, J., Normark, S. \& Hultgren, S. J. (1992). P pili in uropathogenic E. coli are composite fibres with distinct fibrillar adhesive tips. Nature 356, 252-255.

Le Bouguenec, C., Archambaud, M. \& Labigne, A. (1992). Rapid and specific detection of the pap, afa, and sfa adhesin-encoding operons in uropathogenic Escherichia coli strains by polymerase chain reaction. J Clin Microbiol 30, 1189-1193.

Lindberg, F., Lund, B., Johansson, L. \& Normark, S. (1987). Localization of the receptor-binding protein adhesin at the tip of the bacterial pilus. Nature 328, 84-87.

Low, D. (1994). Methylation-dependent and Lrp-dependent fimbrial gene regulation in Eschericbia coli. In Molecular Genetics of Bacterial Pathogenesis, pp. 423-436. Edited by V. L. Miller, J. B. Kaper, D. A. Portnoy \& R. R. Isberg. Washington, DC: American Society for Microbiology.

Lund, B., Marklund, B.-I., Strömberg, N., Lindberg, F., Karlsson, K.-A. \& Normark, S. (1988). Uropathogenic Escherichia coli can express serologically identical pili of different binding specificities. Mol Microbiol 2, 255-263.

Maitii, S. N., Harel, J. \& Fairbrother, J. M. (1993). Structure and copy number analyses of $p a p$, sfa-, and afa-related gene clusters in F165-positive bovine and porcine Escberichia coli isolates. Infect Immun 61, 2453-2461.

Mait, S. N., DesGroseillers, L., Fairbrother, J. M. \& Harel, J. (1994). Analysis of genes coding for the major and minor fimbrial subunits of the Prs-like fimbriae F165 ${ }_{1}$ of porcine septicemic Eschericbia coli strain 4787. Microb Pathog 16, 15-25.

Maniatis, T., Fritsch, E. F. \& Sambrook, J. (1982). Molecular Cloning: a Laboratory Manual. Cold Spring Harbor, NY : Cold Spring Harbor Laboratory.

Marklund, B.-I., Tennent, J. M., Garcia, E., Hamers, A., Båga, M., Lindberg, F., Gaastra, W. \& Normark, S. (1992). Horizontal gene transfer of the Escherichia coli pap and prs pili operons as a mechanism for the development of tissue-specific adhesive properties. Mol Microbiol 6, 2225-2242.

Marmur, J. (1961). A procedure for the isolation of deoxyribonucleic acids from microorganisms. $J$ Mol Biol 5, 208-218.

Norgren, M., Båga, M., Tennent, J. M. \& Normark, S. (1987). Nucleotide sequence, regulation and functional analysis of the $p a p C$ gene required for cell surface localization of Pap pili of uropathogenic Eschericbia coli. Mol Microbiol 1, 169-178.

Nou, X., Skinner, B., Braaten, B., Blyn, L., Hirsch, D. \& Low, D. (1993). Regulation of pyelonephritis-associated pili phase-variation in Escbericbia coli: binding of the PapI and the Lrp regulatory proteins is controlled by DNA methylation. Mol Microbiol 7, 545-553.

Ørskov, I. \& Ørskov, F. (1983). The serology of Escherichia coli fimbriae. Prog Allergy 33, 80-105.

Plos, K., Carter, T., Hull, S., Hull, R. \& Svanborg Edén, C. (1990). Frequency and organization of pap homologous DNA in relation to clinical origin of uropathogenic Escherichia coli. I Infect Dis 161, 518-524.

Pourbakhsh, S. A. \& Fairbrother, J. M. (1994). Purification and characterization of P fimbriae from an Escherichia coli strain isolated from a septicemic turkey. FEMS Microbiol Lett 122, 313-318.

de Ree, J. M., Schwillens, P. \& van den Bosch, J. F. (1985). Molecular cloning of F11 fimbriae from uropathogenic Escherichia coli and characterization of fimbriae with polyclonal and monoclonal antibodies. FEMS Microbiol Lett 29, 91-97.

Reed, K. C. \& Mann, D. A. (1985). Rapid transfer of DNA from agarose gels to nylon membranes. Nucleic Acids Res 13, 7207-7221.

Strömberg, N., Marklund, B.-I., Lund, B., Ilver, D., Hamers, A., Gaastra, W., Karlsson, K.-A. \& Normark, S. (1990). Host-specificity of uropathogenic Escherichia coli depends on differences in binding specificity to Gala1-4Gal-containing isoreceptors. EMBO J 9, 2001-2010

Tennent, J. M., Lindberg, F. \& Normark, S. (1990). Integrity of Escherichia coli $\mathrm{P}$ pili biogenesis: properties and role of PapJ. Mol Microbiol 4, 747-758.

Received 3 January 1996; revised 7 June 1996; accepted 13 June 1996 